\title{
DESCRIPTION OF A NEW GENUS (BATRACHOMYIA,
}

W. S. MACLEAY, MS.), AND TWO SPECIES OF

DIPTEROUS INSECTS PARASITIC UPON

AUSTRALIAN FROGS.

By Frederick A. A. Skuse.

(Plate $\mathbf{x}$ )

More than twenty years ago Mr. George F. Angas reared a Dipterous insect from a small frog, Cystignathus Sydneyensis, Kr. (=Crinia signifera), for which Mr. W. S. Macleay devised the appropriate appellation Batrachomyia, but did not characterize the newly discovered genus. The original specimen was deposited in the Australian Museum. The first printed record we have relating to Batrachomyia is a note by Mr. Gerard Krefft (then Curator of the Australian Museum), read before the Entomological Society of N.S.W., in 1863 (Trans. I. p. 100), giving an account of the metamorphoses of a fly reared by him from another frog, (Uperoleia) Hyperolia marmorata, which he considered to belong to the same genus as the above-mentioned fly, but which to all appearance represented another species; the author also roughly figures different stages of the insect's existence, and gives a diagram of the wing of the imago. Mr. Krefft says that the parasite is most common upon Cystignathus Sydneyensis (Crinia signifera), though he has met with it upon Pseudophryne Bibronii; and he observes that whenever he found specimens of Hyla Citropus they were always infested with them; but although the larvæ all reached the pupa state he could not succeed in keeping them alive afterwards; only in the case of $U$. marmorata had the attempt been successful. Both these specimens appear to have been subsequently mislaid, for Mr. Olliff has on more than one occasion searched in vain for them in the Entomological 
Collection of the Australian Museum; I have, however, lately found a single specimen each of the pupa and imago labelled "Batrachomyia 4-lineata; in frogs of N.S.W.," in the collection of the late Mr. W. S. Macleay.

Between the months of June and December of last year Mr. J. J. Fletcher obtained and kindly handed over to me three frogs infested with Dipterous larvæ which I have in all cases successfully bred out; I am therefore enabled to publish the characters of the genus, and in addition to compare the few notes I have been able to make with those of Mr. Krefft.

As pointed out by $\mathrm{Mr}$. Krefft, the larvæ are found between the skin and flesh on different parts of the sides and back of the frogs ; sometimes only one parasite is present, at others two or three, whilst a spirit specimen of Helioporus albopunctatus from W. Australia, in the Macleay Museum, nursed as many as five. After the emergence of the fly-larvæ the frogs seemed little or none the worse, though according to Mr. Krefft's statement they ought to have succumbed to the effects of the parasites. His frogs, however, may have died of starvation. The presence of a full grown larva is indicated by a glandular-looking swelling of the skin about half an inch in length and having a small aperture at one end. Having lived in their host for a certain at present unknown time, the larvæ leave their nidus and crawl away to some dark and damp situation (such as the underside of a $\log$ or a stone*), become quiescent; while their skin hardens gradually, blackens, and becomes the puparium. The newly emerged larva is extremely averse to the light, crawls very slowly, moving the anterior portion of its body from side to side as if surveying the situation or looking for some convenient spot in which to pupate.

As all my larvæ, except one, emerged and assumed the next stage during the night, and as I was unwilling to sacrifice the only live specimen which I had the brief opportunity of examining, besides its being the only example reared from Pseud. Bibronii, I can

* Last October, I found in a damp umbrageous spot on Saddle-back Mlountain, near Kiama, a puparium attached to the underside of a leaf. 
simply give a very general description of its appearance. There may be marked specific distinctions between the larvæ of different species. Mr. Krefft mentions that the larva found by him in Hyla Citropus varied in structure considerably from all others. I must postpone for the present a critical examination of the mouth-parts. The living larva is pale lemon-yellow, very soft, glabrous, with the skin pellucid; elliptic-ovate, 11-segmented (including head), with very indistinct stigmata; head with two divaricate tentacles; posterior extremity of the body furcate. The posterior tentacles evidently aid in progression.

Pupa exhibiting the general appearance of the imago, entirely enveloped in an extremely delicate transparent skin fitting glovelike round the insect. Arista of the antennæ overlapping the eyes at the tip, directed sidewards. On the underside the wings reach to ahout the posterior margin of the second abdominal segment, but are separated from each other at the tips. Fore and intermediate legs beginning at the shoulders (with the tibiæ) running between the wings, the fore tarsi reaching to a little above the extremity of the wings, the intermediate terminating level with the extremity. Tarsi of the hind-legs issuing from under the wings just before the tip, almost touching at the tips, nearly reaching the posteriur margin of the fourth abdominal segment.

Puparium exhibiting the general appearance of the larva, black, opaque, with more or less distinct transverse wrinkles.

Six species of Australian frogs at least are known to be subject to the attacks of Batrachomyia, but at present it cannot be stated definitely whether or no each species of frog harbours its own special species of fly, though as both the flies now described were only bred from particular frogs, it seems not at all improbable that this will ultimately be found to be constantly the case with all species.

The specimen in the Macleay collection named Batrachomyia quadrilineata, belongs to the same species as an example reared by me from Pseudophryne Bibronii; it is unfortunate that the label of the former does not specify any particular frog.

As far as observations go, the time of year at which the larvæ leave the frog is indefinite, and the duration of the several stages 
of existence from the emergence to the imago state is equally uncertain, as the following table will show; but it is not improbable that the seasonal differences of temperature, and the necessarily artificial conditions under which their hosts lived in confinement may have had something to do with the latter.

\begin{tabular}{|c|c|c|c|c|}
\hline NAME OF FroG. & OBtained. & LARVA EMETRGED. & PUPARIUM FORMED. & FLY EMERGBD, \\
\hline Hyperolia (Uperoleia) & \multirow{3}{*}{$\begin{array}{c}\text { Begin. April. } \\
\text { June } 26 .\end{array}$} & \multirow{3}{*}{$\begin{array}{c}\text { "In a few days." } \\
\text { July } 16 .\end{array}$} & \multirow{3}{*}{$\begin{array}{l}\text { "In } 36 \text { hours." } \\
\text { During night. }\end{array}$} & \multirow{3}{*}{$\begin{array}{c}32 \text { days. } \\
*\end{array}$} \\
\hline marmorata .......... & & & & \\
\hline $\begin{array}{l}\text { Hyla phyllochroa....... } \\
\text { (Containing three larvæ.) }\end{array}$ & & & & \\
\hline & , & July 17. & ", & 62 days. \\
\hline $\begin{array}{l}\text { Hyla phyllochroa........ } \\
\text { (Containing one larva). }\end{array}$ & $\begin{array}{c}, \\
\text { Nov. } 10 .\end{array}$ & $\begin{array}{c}\text { July } 19 . \\
\text { December } 1 .\end{array}$ & , & $\begin{array}{l}63 \text { days. } \\
24 \text { days. }\end{array}$ \\
\hline $\begin{array}{l}\text { Pseudophryne Bibronii } \\
\text { (Containing one larva). }\end{array}$ & , & January 30. & $\begin{array}{l}\text { During day. } \\
\text { (in about } 12 \text { hours?) }\end{array}$ & 22 days. \\
\hline
\end{tabular}

* One puparium was opened on September 4 th in order to obtain the pupa for descriptive purposes,

N.B.-In rearing the larvæ I have followed the course adopted by Mr. Krefft, of placing the frog in a glass vessel provided with damp moss and earth.

\section{Batrachomyia, gen. nov. (W. S. Macleay, MSS.)}

Head transverse, as broad as the thorax; vertex with a very few short bristles; front flattened; face oblique. Eyes rather rounded, but higher than broad. Antennæ very short, not reaching the epistoma; third joint twice the length of the second, nearly round, a little emarginate at the base; sixth slender, bare (pl. x., fig. 10). Thorax rather longer than broad, with a few short lateral bristles; transverse suture distinct at each side; scutellum rather small, semicircular, rounded at the corners, fringed with short bristles. Abdomen ovate, five-segmented ; first segment large, as long as the three next following; last two segments and anal joint much narrower than the preceding segments, curved downwards. Legs 
of moderate length and thickness; tibiæ without bristles, the intermediate pair with very small spurs; hind femora slender; hind tibiæ slightly curved (pl. x., fig. 9). Wings rather short and broad; costal vein without bristles, ending at the tip of the fourth longitudinal; auxiliary vein wanting, its course indistinctly indicated by a pale wing-fold-like line; first longitudinal vein gradually bent, terminating in the costa at a point rather beyond mid-way between the transverse shoulder vein and the tip of the second longitudinal, and opposite the posterior transverse vein; third longitudinal vein originating opposite a point mid-way between the transverse shoulder vein and the tip of the first longitudinal ; hinder transverse vein slanting; foremost of the two small basal cells united with the discal cell, the posterior one entirely wanting; sixth longitudinal vein stopping immediately before reaching the border * (pl. x., fig. 7).

Obs.-Judging by the above characters this genus might be considered identical with Oscinis, but the far greater size and peculiar habits of the contained species both give it an unmistakable distinction, and to my mind justify the retention of Mr. Macleay's generic name.

BATRACHOMYia NIGRITARSIS, sp.n.

§.-Long $2 \frac{3}{4}$; alar. $2 \frac{1}{2}$ lines; ㅇ long $3 \frac{1}{2}$; alar. $3 \frac{1}{4}$. Antennæ entirely black. Head ferruginous-ochre; the pubescence on the front and short bristles on the vertex black. Ocelli on a small deep brown or black triargular patch. Eyes black, with pale yellow pubescence. Thorax ochreous-brown, shining, densely covered with short black hairs; very indistinct traces of four light brownish bands similarly disposed to those in B. quadrilineata; pleuræ and pectus bright ochreous or ferruginousochreous, the latter with short yellow hairs; scutellum ochreous or brownish-ochreous with short black hair, fringed at the apex

* This vein runs so close to the border that the fact of its really rot reaching it can only be ascertained by very close examination with the ordinary lens. 
with short black bristles; metanotum ochreous-brown, shining. Halteres pale ochre-yellow or brownish-ochreous. Abdomen shorter than the thorax (in dried specimens), as broad as it or a little broader, shining, castaneous, tinged with ochreous-brown, the last two segments wholly ochreous in the $ᄋ$; clothed with short black hairs, intermixed with some yellowish hairs in the $Q$; anal joint in the 0 nodose, in the $Q$ pointed. Legs densely clothed with yellow hairs. Coxæ⿱ and femora ochreous, the latter black at the apex. Tibire and tarsi black, the hind tibiæ ochreous or brownish-ochreous, black at the base and apex; ungues black. Wings considerably tinted with yellow on the anterior portion of the basal half, the remainder hyaline: veins dark brown, ochreous-brown towards the base of the wing; very pale reflections. Middle transverse vein erect in the $\hat{\jmath}$, slanting in the $Q$; posterior transverse vein straight, separated from the middle transverse vein a distance equal to twice its length (rather more than this in the o), and at a point mid-way between the latter and the tip of the fifth longitudinal vein.

Larva, , long $5 \frac{1}{2}$; broad 2 lines. Puparium, $\hat{\delta}$, long $4 \frac{1}{2}$; broad 2 . $\quad$, long $5 \frac{1}{2}$; broad $2 \frac{1}{4}$.

Hab.-Illawarra, \&c., N.S.W. Bred from two specimens of Hyla phyllochroa, obtained by Mr. Fletcher in June and November, respectively.

Batrachomyia quadrilineata, sp.n. (W. S. Macleay, MSS.)

J.--Long $2 \frac{1}{2}-3$; alar. $2 \frac{1}{4}$ lines. Antennæ ochreous-brown or ferruginous, the arista deep brown or black. Head ochreous or ferruginous-ochre; the pubescence on the front and short bristles on the vertex black. Ocelli on a small deep brown or black triangular patch. Eyes black (deep olivaceous whilst living), with pale yellow pubescence. Thorax ochreous-brown, shining, rather densely covered with short yellow hairs; traversed by four parallel longitudinal narrow bands of black, the lateral ones somewhat broader than the median two, starting below the humeri, completely interrupted near the anterior extremity by the transverse suture (thus cutting off a squarish portion), not 
reaching as far as the scutellum, the median ones close together, starting from the anterior margin, not reaching quite as far posteriorly as the lateral ones; pleuræ and pectus ochreous or ochreous-brown, the latter with yellow hairs; a small black spot before the intermediate coxæ, and another much smaller almost linear before the hind coxæ; scutellum ochreous or brownishochre, shining, covered with short black hairs, fringed at the apex with short black bristles; metanotum shining black. Halteres pale ochre-yellow, more brownish towards the base of the stem. Abdomen shorter than the thorax (in dried specimens), as broad as it or a little narrower, brown, more or less castaneous, tinged with ochreous, shining, clothed with short yellow hairs. Legs brownish-yellow, with a dense short yellow pubescence; ungues brown. Wings very slightly ochreous at the base, hyaline, the veins dark brown or blackish, ochreousbrown towards the base of the wing; delicate opaline reflections. Middle transverse vein erect; posterior transverse vein slightly bent, separated from the middle transverse vein a distance equal to scarcely twice its length, and at a point rather nearer to the latter than to the tip of the fifth longitudinal vein (pl. x., fig. 7 ).

Larva, long $4 \frac{1}{4}$; broad $1 \frac{3}{4}$ lines. Puparium, long 4 ; broad $1 \frac{4}{5}$ lines; with rather more distinct transverse wrinkles than in the last species.

Hab.-Burrawang, N.S.W. Bred from specimen of Pseudophryne Bibronii obtained by Mr. Fletcher in November.

\section{EXPLANATION OF PLATE X.}

Fig. 1. Larva of Batrachomyia quadrilineata.

Fig. 2. Pupa of Batrachomyia nigritarsis (back view).

Fig. 3.

Fig. 4. 5. Puparium of Batrachomyia nigritarsis.

Fig. 5a.

,

,, anterior portion detached on the escape of the imago.

Fig. 6. Batrachomyia quadrilineata.

Fig. 6a. ,, , natural size.

Fig. 7. Diagram of wing of Batrachomyia quadrilineata.

Fig. 8. Head

Fig. 9. Hindleg $\}$ of Batrachomyia quadrilineata.

Fig. 10. Antenna

12 


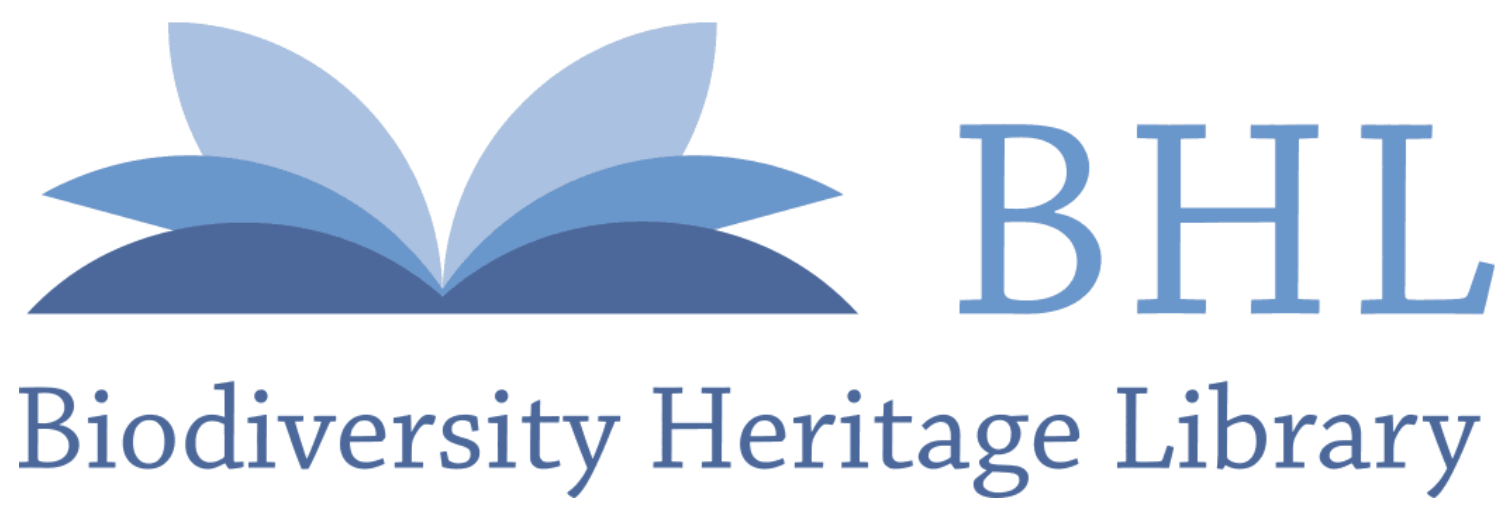

Skuse, Frederick A. A. 1889. "Description of a new genus (Batrachomyia, W. S. Macleay, MS.), and two species of dipterous insects parasitic upon Australian frogs." Proceedings of the Linnean Society of New South Wales 4, 171-177. https://doi.org/10.5962/bhl.part.15042.

View This Item Online: https://www.biodiversitylibrary.org/item/29780

DOI: https://doi.org/10.5962/bhl.part.15042

Permalink: https://www.biodiversitylibrary.org/partpdf/15042

\section{Holding Institution}

MBLWHOI Library

\section{Sponsored by}

MBLWHOI Library

\section{Copyright \& Reuse}

Copyright Status: NOT_IN_COPYRIGHT

This document was created from content at the Biodiversity Heritage Library, the world's largest open access digital library for biodiversity literature and archives. Visit BHL at https://www.biodiversitylibrary.org. 